\title{
First report of Aethalion reticulatum (Linnaeus, 1767) (Hemiptera: Aethalionidae) infesting plants of Coffea arabica (Linnaeus, 1753) (Rubiaceae)
}

\author{
Laís Sousa Resende ${ }^{1}\left(\mathbb{D}\right.$, Luciano Bastos Moreira $^{2} \mathbb{D}$, Vinícius Castro Carvalho ${ }^{2}$ (D) , Geraldo Andrade Carvalho ${ }^{2}$ (D)
}

\author{
${ }^{1}$ Escola Superior de Agricultura "Luiz de Queiroz"/ESALQ, Universidade de São Paulo/USP, Departamento de Produção Vegeral/LPV, Piracicaba, SP, Brasil \\ ${ }^{2}$ Universidade Federal de Lavras/UFLA, Departamento de Entomologia/DEN, Lavras, MG, Brasil \\ Contact authors: sialresende@gmail.com; lucianoauburn@gmail.com; vicarvalho06@gmail.com; gacarval@ufla.br \\ Received in March 29, 2021 and approved in June 16, 2021
}

\section{ABSTRACT}

Coffee has great socio-economic importance, and in this scenario, Brazil stands out as the largest producer and exporter of coffee beans. However, the coffee crop is susceptible to the attack of several insect pests, the main ones being the coffee berry borer Hypothenemus hampei (Coleoptera: Curculionidae: Scolytinae) and the leaf miner Leucoptera coffeella (Lepidoptera: Lyonetiidae), which can cause great economic losses if left unchecked. However, other pest arthropods may be present in the crop, and their identification and evaluation of its importance are essential for the elaboration of mitigation measures. Up to date, the presence of the leafhopper Aethalion reticulatum (Hemiptera: Aethalionidae) in Coffea arabica (Rubiaceae) plants has not been reported in the literature. Thus, the present study aimed to describe the occurrence of $A$. reticulatum in Coffea arabica plants on the Campus of the Federal University of Lavras (UFLA), Lavras, Minas Gerais, Brazil.

Key words: Fruit leafhopper; Insect pest; Coffee crop; Infestation.

\section{INTRODUCTION}

Brazil is the largest producer and exporter of coffee beans in the world, and Minas Gerais State is the main producing region, responsible for approximately $55 \%$ of national production (Companhia Nacional do Abastecimento - CONAB, 2021). In the 2019/2020 harvest, the country exported 44.67 million bags with revenue of 5.6 billion dollars (Conselho dos Exportadores de Café do Brasil - CECAFÉ, 2020). Coffee production occupies a total of 2.71 million hectares with an estimated production of 49.5 million $60 \mathrm{~kg}$ bags and an average productivity of 28.24 per hectare (CONAB, 2021). However, this production can be reduced by several factors, among which stands out the attack of insect pests.

The leaf miner Leucoptera coffeella (Guérin-Mèneville Perrottet, 1842) (Lepidoptera: Lyonetiidae) and the coffee berry borer Hypothenemus hampei (Ferrari, 1867) (Coleoptera: Curculionidae: Scolytinae) are the main insect pests of the coffee crop in Brazil and they are generally controlled with insecticides. The frequent use of insecticides from the chemical groups of organophosphates, pyrethroids and carbamates to control these pests can lead to outbreaks of secondary pests such as the red mite Oligonychus ilicis (McGregor, 1917) (Acari: Tenuipalpidae) (Souza et al., 1998).

Another secondary pest of coffee is the mite Brevipalpus phoenicis (Geijskes, 1939), known to be a vector of the coffee ring spot virus (CoRSV), which in very favorable conditions, this disease can cause intense leaf loss. Sucking insects such as the Quesada gigas (Olivier, 1790), Carineta fasciculata (Germar, 1830), Fidicina pronoe (Walker, 1850), Carineta spoliata (Walker, 1858), Carineta matura (Distant, 1892) cicadas (Hemiptera: Cicadidae), and the root insects Dysmicoccus cryptus (Hempel, 1918), green scale Coccus viridis (Green, 1889) (Hemiptera: Coccidae), citrus mealybug Planococcus citri Risso, 1813 (Hemiptera: Pseudococcidae) and the citrus orthezia Orthezia praelonga Douglas, 1891 (Hemiptera: Ortheziidae) are also found in the crop, but occur occasionally. Some chewing insects like the imperial moth Eacles imperialis (Walker, 1856), Lonomia circumstans Walker, 1855 (Lepidoptera: Saturniidae), bagworm Oiketicus kirbyi (Lands-Guilding, 1827) (Lepidoptera: Psychidae), fuller rose beetle Naupactus cervinus (Boheman, 1840) (Coleoptera: Curculionidae), termites Cornitermes sp. and Procornitermes sp. (Isoptera: Termitidae) are also found in coffee plants as secondary pests (Gallo et al., 2002).

Despite the large number of pests associated with coffee, the presence of the leafhopper Aethalion reticulatum (Linnaeus, 1767) (Hemiptera: Aethalionidae) has not been reported in the crop until now. It is a piercing and sap-sucking insect which adults and nymphs feed on plant stem (Vanin et al., 2008) of different hosts, mainly fruit, such as cashew, citrus, fig, mango and tamarind (Gallo et al., 2002). Furthermore, this species can be an important pest of orchards because impair the development of plants and the formation of fruits or new shoots and the plant can finally die (Araújo et al., 2010). Also, this species has a gregarious behavior, i.e., and lives in colonies formed by young apterous insects and winged adults. This species has been identified in different hosts such as Dipteryx 
alata (Souza; Boscardin, 2020), Morinda citrifolia (Castro; Montalvão, 2019), Triplaris americana (Pires et al., 2015), Erythrina speciosa (Zanuncio et al., 2015), and Eucalyptus cloeziana (Menezes et al., 2012). The adults measure approximately $10 \mathrm{~mm}$ in length, have a rust-brown color and the venation of their wings are greenish with protruding ribs (Gallo et al., 2002; Santos; Creão Duarte; Lunz, 2015). Rando and Lima (2010) observed that the colonies of A. reticulatum were preferentially found in the basal part of the tree, next to $40-\mathrm{mm}$ diameter branch bifurcations, with low incidence of sunlight, and even if stimulated, they did not endorse the colony's gregarious habit.

The biological cycle of $A$. reticulatum lasts about 110 days (egg to adult), with the nymphal stage lasting approximately 45 days, going through five instars, which allows the development of up to three generations per year. The average longevity of adult insects is 60 days, during which the females lay up to 100 eggs, which are deposited in masses on the surface of the plant tissue and surrounded by a brownish or grayish substance for protection. Nymphs of A. reticulatum emerge after 30 days of oviposition, and during the embryonic period, the females protect the eggs while remaining on the mass (Vieira et al., 2007).

The leafhoppers have a filter chamber digestive system type, which allows assimilation of aminoacids and elimination of excess plant sap (water and sugar) in the form of "honeydew", used as food by the sooty mold fungus Capnodium sp. The presence of sooty mold on plant tissue causes a reduction in photosynthesis by reducing absorption capacity and the production of photoassimilates by plants, in addition to hindering transpiration and respiration, leading to reduced productivity. The "honeydew" consists of sugars such as glucose, fructose and sucrose, aminoacids, lipids, starch, vitamins and minerals, which attracts other insects to the host plant, such as ants belonging to the genus Camponotus (Fowler, 1992). These hymenopterans protect the colonies of $A$. reticulatum against predators and in return maintain their food source (Blüthgen et al., 2000). There are also other symbiotic insects such as the wasp Synoeca septentrionalis Richard, 1978 (Hymenoptera: Vespidae) and stingless bees belonging to the Meliponini tribe, especially Trigona spp. (Santos; Creão-Duarte; Lunz, 2015; Rando; Lima, 2010).

Thus, the objective of the present work is to describe for the first time the occurrence of the $A$. reticulatum leafhopper in Coffea arabica plants in the state of Minas Gerais.

\section{MATERIAL AND METHODS}

Leafhoppers infesting coffee plants were identified in an area located at latitude $21^{\circ} 13^{\prime} 36.47^{\prime \prime}$ South, longitude $44^{\circ} 57^{\prime} 40.35^{\prime \prime}$ West and altitude of 975 meters above sea level, in the city of Lavras, Minas Gerais, Brazil.
The planting of the area was carried out in January 2016, with seedlings of the cultivar "Mundo Novo 379-19" on the Campus of the Federal University of Lavras (UFLA) (Figures 1A and B).The spacing was 3.6 meters between the rows and 0.75 meters between plants. In October 2017, one year and ten months after planting, a colony of $A$. reticulatum was observed in coffee plants.

The images of the insects were obtained using an Olympus $^{\circledR}$ E-410 digital camera, and the adult leafhoppers were taken to the Ecotoxicology Laboratory of the Entomology of the Federal University of Lavras for identification.

\section{RESULTS}

Leafhoppers were identified as $A$. reticulatum. The analyzed plants had flowers (Figures $1 \mathrm{~A}$ and 1B) and nymphs and adults of the insect were found. The insects were found mainly in the youngest branches of the plant and close to the fruits. The colony was formed by 50 insects, being 30 nymphs and 20 adults (Figure 1C). The adults and nymphs suck the sap from the plant, damaging the development of fruits and shoots, and in high infestations can kill the plant. Camponotus spp. ants (Hymenoptera: Formicidae) were also found in association with the leafhoppers in this study.

\section{DISCUSSION}

Recognized as an important fruit pest insect, $A$. reticulatum has a wide geographic distribution, being found in Central American and South American countries (Marques, 1928). In Brazil, there are reports of the occurrence of $A$. reticulatum in three states in the southern region (PR, SC and $\mathrm{RS}$ ), four in the southeast region (MG, ES, SP and RJ), as well as in other states such as Bahia, Ceará and Amazonas (Santana et al., 2005).

However, reports in the literature demonstrate the occurrence of this insect in other host plants such as Grevillea robusta Allan Cunningham, 1830 (Proteaceae), known as southern silky oak, a plant originally from Australia and cultivated as an ornamental plant and for windbreak and shading for agricultural crops (Santana et al., 2005). In Acre, a state in northern Brazil, Santos, Creão-Duarte and Lunz (2015) described the occurrence of $A$. reticulatum in a plant of Euterpe oleracea Martius, 1824 (Arecaceae), popularly known as "açaí", of great economic importance for the region. Zanuncio et al. (2015) observed the occurrence of this insect in the state of Rio de Janeiro in Erythrina speciosa Andrews (Fabaceae), an ornamental plant known as coral tree. Rando and Lima (2010) reported the presence of this leafhopper in Ocimum gratissimum L. (Lamiaceae), widely used as a medicinal plant due to its therapeutic potential, as well as 


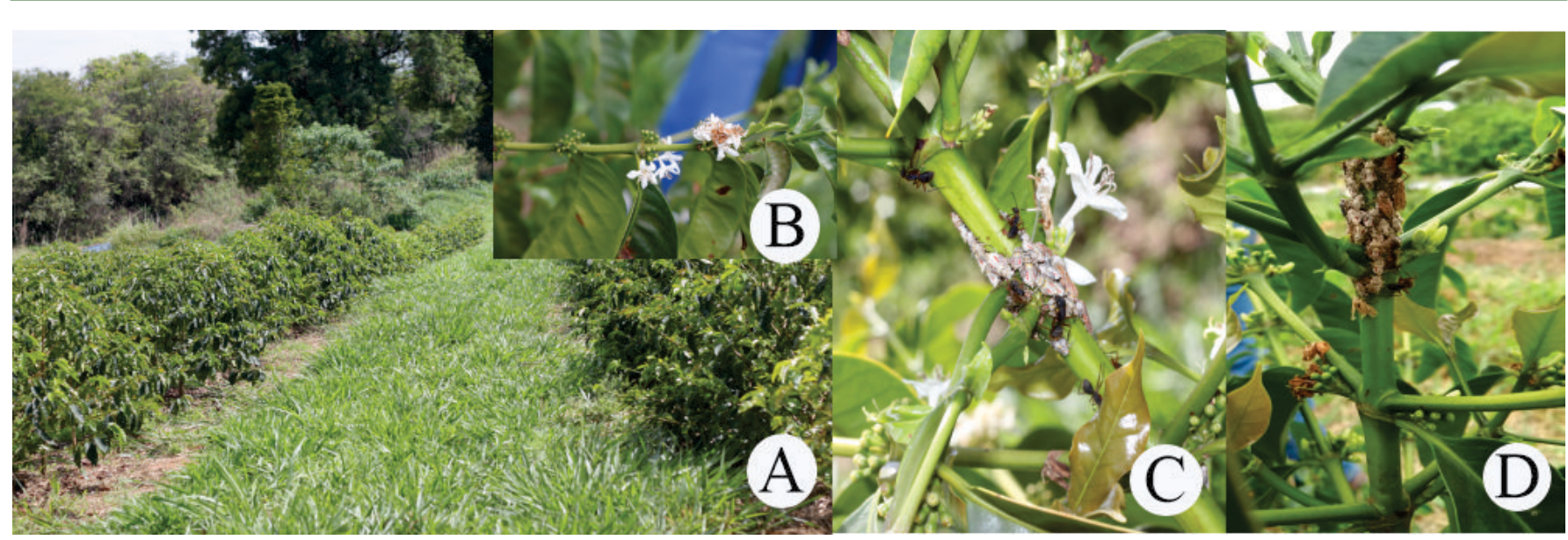

Figure 1: Aethalion reticulatum (Linnaeus, 1767) (Hemiptera: Aethalionidae) and Coffea arabica (Linnaeus, 1753) (Rubiaceae). (A) Coffee crop cultivation Mundo Novo 379-19, (B) Inflorescence of C. arabica, (C and D) colony of $A$. reticulatum in the $C$. arabica plant and Camponotus spp. ants.

Menezes et al. (2013) reported the presence of this Hemiptera in Vernonia condensata Baker, 1875 (Asteraceae), a Brazilian medicinal plant, commonly known as figatil. The presence of A. reticulatum feeding on plants of Eucalyptus cloeziana F. Muell, 1878 (Myrtaceae) was reported by Menezes et al. (2012). This widespread occurrence demonstrates the potential for infestation of this insect pest not only on fruit trees, but also on other hosts, and it may become an important pest in other crops, such as coffee crop (Figure 1).

Therefore, $A$. reticulatum has been detected in coffee crop for the first time and it has potential to become an important pest of this crop. Several pest management strategies can be used against the $A$. reticulatum, such as monitoring the infested and nearby areas for the occurrence and possible population fluctuation of the insect, to verify the need to implement control measures, as well as to identify the presence of its natural enemies that will help in the regulation of the population density of the pest insect in the crop.

For monitoring of $A$. reticulatum is possible to use traps, as it is used for the monitoring and control of coffee berry borer. Fernandes et al. (2011) evaluated the levels of economic damage caused by this insect using red traps with an alcohol mixture. The use of these traps allows the detection of the beginning of coffee berry borer infestation in the field, and when the first adults initially arrive in the cultivated area; in that way, their use helps in the decisions and adoption of pest management strategies in the crop. Another study conducted by Fernandes et al. (2014), using red PET-bottle traps reduced the percentage of drilled berries in $57 \%$. However, the use of these traps as the only method of control does not solve the problem, and other strategies is necessary (Fernandes et al., 2014; Infante, 2018). In view of this, new studies should be carried out for the development of attractive traps for $A$. reticulatum to monitor and even control this leafhopper in coffee crop.

Insecticides are widely used to control pests. However, there are no products registered for the control of this leafhopper in coffee crop. Nevertheless, phosphorus insecticides, carbamates or growth regulators are recommended, as chemical control options of this leafhopper in other crops (Gallo et al., 2002).

The presence of natural enemies is also important to manage this pest. A research carried out by Conceição, Guerreira-Filho and Gonçalves (2005) in which the authors observed the population fluctuation of $L$. coffeella in different coffee cultivars, as well as the presence of natural enemies. The researchers reported two peaks of leaf miner infestation throughout the year, which provided growers with important information for planning insect control strategies. In the literature are reported as natural enemies of leafhopper, Pterygrogramm marquesi (Brèthes) (Hymenoptera: Trichogrammatidae) (Sutil; Santos, 2020), Aulacothrips dictyotus (Hood) (Thysanoptera: Heterothripidae) (Izzo; Pinent; Mound, 2002), and Uscanoidea silvestrii (Viggiani) (Hymenoptera: Trichogrammatidae) (Viggiani, 1992).

This note reports the first occurrence of $A$. reticulatum insects in C. arabica, in Lavras city, Minas Gerais State, Brazil. Our observations show that this plant is a potential host of this leafhopper, described as an insect pest in agricultural crops, and for this it is essential to expand our knowledge about your life cycle in the coffee crop, as well as of control measures.

\section{CONCLUSION}

This is the first report of the occurrence of $A$. reticulatum in the coffee crop. 


\section{ACKNOWLEDGEMENTS}

This research was supported by the Conselho Nacional de Desenvolvimento Científico e Tecnológico (CNPq) Financial code 306892/2017-0, and Fundação de Amparo à Pesquisado Estado de Minas Gerais (FAPEMIG) - Financial code CAG APQ -02118-16.

\section{REFERENCES}

ARAÚJO, V. A. et al. Ultrastructural characterization of the spermatozoa of Aethalion reticulatum Linnaeus 1767 (Hemiptera: Auchenorrhyncha: Aethalionidae). Micron, 41(4):306-311, 2010.

BLÜTHGEN, N. et al. How plants shape the ant community in the Amazonian rainforest canopy: The key role of extrafloral nectarines and homopteran honeydew. Oecologia, 125(2):229-240, 2000.

CASTRO, M. T.; MONTAlVÃO, S. C. L. Primeiro relato de Aethalion reticulatum (L.)(Hemiptera: Aethalionidae) infestando plantas de noni [Morinda citrifolia L. (Rubiaceae)]. EntomoBrasilis, 12(2):8183, 2019.

\section{COMPANHIA NACIONAL DO ABASTECIMENTO -} CONAB. Acompanhamento da safra brasileira de café: safra 2021: primeiro levantamento. Brasília: Conab, 2021. 72p.

\section{CONSELHO DOS EXPORTADORES DE CAFÉ DO} BRASIL - CECAFÉ. Brasil: Exportação anual. 2020. Available in: https://www.cecafe.com.br/dadosestatisticos/exportacoes-brasileiras/. Access in: March 2021.

CONCEIÇÃO, C. H. C.; GUERREIRO-FILHO, O.; GONÇALVES, W. Flutuação populacional do bichomineiro em cultivares de café arábica resistentes à ferrugem. Bragantia, 64(4):625-631, 2005.

FERNANDES, F. L. et al. Economic injury level for the coffee berry borer (Coleoptera: Curculionidae: Scolytinae) using attractive traps in Brazilian coffee fields. Journal of Economic Entomology, 104(6):19091917, 2011.

FERNANDES, F. L. et al. Controle massal da brocado-café com armadilhas de garrafa Pet vermelha em cafeeiro. Pesquisa Agropecuária Brasileira, 49(8):587$594,2014$.

FOWLER, H. G. Aethalzonzdae: Functional equivalents of extrafloral nectaries in Bauhznza (Cesalpinionidae). Anales de Biología, 18(7):155-159, 1992.
GALLO, D. et al. Entomologia agrícola. Piracicaba: FEALQ, 2002. 920p.

INFANTE, F. Pest management strategies against the coffee berry borer (Coleoptera: Curculionidae: Scolytinae). Journal of Agricultural and Food Chemistry, 66(21):5275-5280, 2018.

IZZO, T. J.; PINENT, S. M.; MOUND, L. A. Aulacothrips dictyotus (Heterothripidae), the first ectoparasitic thrips (Thysanoptera). Florida Entomologist, 85(1):281-283, 2002.

MARQUES, L. A. A. Cigarrinha nociva a várias espécies vegetais: Biologia do membracídeo Aethalium reticulatum (L.). Instituto Biológico de Defesa Agrícola e Animal, Boletim 6, 1928. 27p.

MENEZES, C. W. G. et al. Novos insetos sugadores (Hemiptera) atacando Eucalyptus cloeziana (Myrtaceae) em Minas Gerais, Brasil. EntomoBrasilis, 5(3):246-248, 2012.

MENEZES, C. W. G. et al. First record of Aethalion reticulatum (Hemiptera: Aethalionidae) in Vernonia condensata (Asteraceae), a medicinal plant from Brazil. Phytoparasitica, 41(5):611-613, 2013.

RANDO, J. S. S; LIMA, C. B. Detecção de Aethalion reticulatum (Linnaeus, 1767) (Hemiptera: Aethalionidae) em alfavaca-cravo (Ocimum gratissimim L.) e observações sobre sua ocorrência. Revista Brasileira de Plantas Medicinais, 12(2):239-242, 2010.

SANTANA, D. L. Q. et al. Ocorrência de Aethalion reticulatum (Linnaeus, 1767) (Hemiptera: Aethalionidae) em Gravillea robusta. Boletim de Pesquisa Florestal, (50):109-115, 2005.

SANTOS, R. S.; CREÃO-DUARTE, A. J.; LUNZ, A. M. P. Infestação de Aethalion reticulatum (Linnaeus, 1767) (Hemiptera: Auchenorrhyncha: Aethalionidae) em plantas de Euterpe oleracea Martius (Arecaceae) no estado do Acre. EntomoBrasilis, 8(1):69-73, 2015.

SOUZA, J. C. et al. Bicho-mineiro do cafeeiro: Biologia, danos e manejo integrado. 2.ed. Belo Horizonte: EPAMIG, (Boletim Técnico n.54), 1998. 48p.

SOUZA, S. J; BOSCARDIN, J. Occurrence of Aetalion reticulatum (Linnaeus) (Hemiptera: Aethalionidae) on Dipteryx alata Vogel (Fabaceae) in Minas Gerais, Brazil. EntomoBrasilis, 13:e930, 2020.

SUTIL, W. P.; SANTOS, R. S. Agricultural entomology in the state of Acre: A historical overview and future challenges. EntomoBrasilis, 13:e0878, 2020. 
PIRES, E. M. et al. Triplaris americana L. (Polygonaceae), a new host plant for Aethalion reticulatum (Linnaeus, 1767) (Hemiptera: Aethalionidae). Brazilian Archives of Biology and Technology, 58(1):31-33, 2015.

VANIN, S. A. et al. Insect feeding preferences on piperaceae species observed in São Paulo city, Brazil. Revista Brasileira de Entomologia, 52(1):72-77, 2008.

VIEIRA, C. U. et al. Interação entre Trigona spinipes Fabricius, 1793 (Hymenoptera: Apidae) e Aethalion reticulatum Linnaeus, 1767 (Hemiptera: Aethalionidae) em Mangifera indica (Anacardiaceae). Bioscince Journal, 23(1):10-13, 2007.

VIGGIANI, G. New species of Trichogrammatidae (Hymenoptera: Chalcidoidea) from South America. Redia, 75(1):253-254, 1992.

ZANUNCIO, A. J. V. et al. Aethalion reticulatum (Hemiptera: Aethalionidae) feeding on Erythrina speciosa (Fabales: Fabaceae): First record of its host plant and damage characteristics. Florida Entomologist, 98(1):175-177, 2015. 